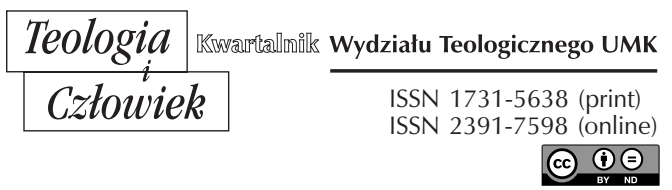

51(2020)3, ss. 11-27

WITOLD PIOTR GLINKOWSKI

\title{
TISCHNER CZYTA HEIDEGGERA - METAMORFOZY PYTANIA O CZŁOWIEKA
}

DOI: http://dx.doi.org/10.12775/TiCz.2020.036

Streszczenie. Ks. Józef Tischner należy do najwcześniej aktywizujących się polskich translatorów i komentatorów myśli Heideggera. Jego „czytanie Heideggera” przyniosło wieloraki plon, nie tylko w postaci precedensów translacyjnych, ale przede wszystkim jako źródło inspiracji dla własnego myślenia o Bogu i człowieku. W tym przypadku posiłkowanie się myślą Heideggera staje się tym bardziej interesujące, gdy uwzględnimy oczywistą różnicę między charakterem obu projektów: Heidegger kierował swoją uwagę na problematykę bytu, która jego zdaniem za sprawą jej śródziemnomorsko-europejskiej recepcji uległa pojęciowej deformacji, zapomnieniu, zagubieniu; Tischner interesuje się człowiekiem, jako „myślącym według wartości”, ale też trwającym w dialogu - z Bogiem i z innymi ludźmi - i z tego powodu uwikłanym w dramat istnienia. Człowiek u Tischnera bytuje, podobnie jak Heideggerowskie Dasein, ale ludzkie bytowanie jest zaksjologizowane w sposób antropo- i teocentryczny - jest realizowane przez wolny podmiot, będący osobą pośród osób, otwierający się na Boga, podlegający dialogicznemu "zagadnięciu” o charakterze etycznym i odpowiadający na nie swoją egzystencją. W przypadku człowieka powodem jego ukierunkowania na wartości jest nie tylko i nie przede wszystkim ich wymiar „użytkowy”, a jego „rozumienie się” na wartościach przebiega - inaczej niż w przypadku Dasein - nie z powodu trwogi przenikającej jego bycie ku śmierci i nie tylko z uwagi na „zew sumienia”, ale z uwagi na jego otwarcie na transcendencję rozumianą przede wszystkim w sposób etyczny, a nie ontyczny lub ontologiczny. 
Stawiam sobie zadanie zrekapitulowania tych spośród nawiązań do Heideggera, które zostały przez Tischnera wykorzystane w budowanej przezeń koncepcji człowieka.

Słowa kluczowe: ontologia fundamentalna; antropologia filozoficzna; filozofia dramatu.

Abstract. Tischner reads Heidegger - Metamorphoses of the Question about

Man. Rev. Józef Tischner was one of the earliest translators and commentators on Heidegger's thought. His 'reading of Heidegger' bore various fruit, not only in the form of translation precedents, but above all, as a source of inspiration for thinking about God and man. In this case, the support of Heidegger's thought becomes even more interesting if we take into consideration the obvious difference between the natures of both projects: Heidegger focussed on the issue of existence, which - to his mind - was conceptually deformed, forgotten and lost due to its Mediterranean and European reception. Tischner was interested in man as the one who 'thinks by values', and at the same time, maintains a dialogue with God and other men, and thus, he is entangled in the tragedy of existence. Tischner's man exists, just like Heidegger's Dasein, and yet human existence is axiologized in an athropo- and theocentric manner, i.e., it is performed by a free subject, a person among other persons, open to God, liable to dialogical 'issue' that is ethical in its nature, and responding to it with his own existence. In the case of man, the reason behind his orientation for values is not only and not mainly their 'utilitarian' dimension. His 'comprehension' of values - as opposed to Dasein - progresses not because of the fear that permeates his existence towards death and not only in view of 'the call of conscience', but as a result of his openness to transcendence, understood primarily in an ethical manner, and not ontically or ontologically.

The task that I set myself is to recapitulate the references to Heidegger which Tischner utilised to construct his concept of man.

Keywords: fundamental ontology; philosophical anthropology; philosophy of drama.

Pytanie o człowieka należy niewątpliwie do najważniejszych wątków filozoficznego namysłu. Zaświadcza o tym filozoficzna tradycja przynajmniej od czasów Sokratesa - ale też w myśli współczesnej „problem człowieka” pozostaje nadal obecny, choć różny jest jego status, gdyż coraz rzadziej pojawia się jako zasadnicze zadanie stawiane w obrębie filozoficznych badań. Czasami bywa też tak, że filozof żywo zainteresowany zagadnieniami antropologii filozoficznej i zmierzający do opracowania własnej koncepcji bytu ludzkiego dopatruje się - nie zawsze zasadnie - 
wątków antropologicznych w dorobku innego myśliciela. Niniejszy tekst uwzględnia taki właśnie przypadek, polegający na pewnej nadinterpretacji projektu jednego spośród emblematycznych dla myśli współczesnej filozofów przez innego, który występuje nie tylko w roli „bezstronnego interpretatora", ale też w roli kogoś, kto jako samodzielny autor aktywnie włącza się w filozoficzny dyskurs.

Zapewne wolno zaryzykować tezę, że stosunek ks. Józefa Tischnera do filozoficznego dorobku Martina Heideggera był ambiwalentny. Ten stan rzeczy wynika z podwójnej roli, w jakiej odnajdywał się Tischner. Ten krytyczny komentator myśli współczesnej pragnął rekonstruować ją w sposób rzetelny, ale też wchodząc z nią w wyraźnie autorski dialog, a nawet angażując nieco „zewnętrzną” optykę badawczą. Ów prowadzony przez Tischnera dialog zaświadczał o jego temperamencie i zainteresowaniach - nie zawsze pozostających w koincydencji z obszarem zainteresowań i z badawczą perspektywą przyjmowaną przez jego filozoficznych interlokutorów i mentorów. Ową dwojakość, ale też dwutorowość, które charakteryzują stosunek Tischnera do Heideggera, ilustruje dwukierunkowość podejmowanej przez krakowskiego myśliciela aktywności. Z jednej strony Tischner występuje $\mathrm{w}$ roli popularyzatora Heideggerowskiego projektu, z drugiej strony w sposób krytyczny sekunduje „ontologicznej rewolucji” patronującej filozofii Heideggera, niezależnie od etapu w jakim się ona krystalizowała. Wszelako nie rezygnował z własnych koncepcji, które stopniowo dojrzewając - w dużej mierze właśnie w polemice z Heideggerem - ostatecznie przybrały kształt „filozofii dramatu”'. Ale, co ciekawe, chociaż zdaje sobie sprawę z niewydolności Heideggerowskiej ontologii fundamentalnej, która niezależnie od faktu, iż zawarta w niej analiza Dasein obejmuje zarazem analizę bytu ludzkiego, nie dysponuje odpowiednimi narzędziami, by ujawnić dramatyczny wymiar ludzkiej egzystencji - Tischner próbuje ów wymiar w niej odnaleźć. Toteż stwierdza: „Sam Heidegger nie robi filozofii dramatu, będziemy jednak starali się tak do Heideggera podejść, ażeby z jego filozofii wydobyć jakąś wizję ludzkiego dramatu"2.

1 J. Tischner, Filozofia dramatu, Paryż 1990.

2 Tenże, Dzieła zebrane. Współczesna filozofia ludzkiego dramatu. Wykłady, oprac. D. Kot i A. Węgrzecki, Kraków 2012, s. 141. 


\section{1. "MYŚLENIE WEDłUG WARTOŚCI" - ZAGROŻENIE CZY SZANSA?}

Tischner już we wczesnej fazie swojej przygody z filozofią dał się poznać jako kontestator tradycji tomistycznej, występujący z pozycji dość szeroko i swobodnie asymilowanej fenomenologii. Tradycja ta jego zdaniem w sposób niezasadny monopolizowała dyskurs filozoficzny, a zwłaszcza myślenie o człowieku. Dlatego przeciwstawia jej „myślenie według wartości”, będąc zarazem świadomy oczywistej prowokacji obecnej $\mathrm{w}$ tym sformułowaniu, stanowiącym tytuł jednej z jego najwcześniejszych i najważniejszych publikacji książkowych ${ }^{3}$. Wszak Heidegger, jak wiemy, dyskwalifikował takie myślenie, gdyż jak sądził, przekreśla ono szanse na ujawnienie „prawdy bycia”. W owym myśleniu upatrywał residuum dawnej antropocentrycznej metafizyki. Dlatego też Tischner, jako tłumacz Listu o humanizmie, z którego pochodzą słowa - „Myślenie podług wartości jest tu i wszędzie największym bluźnierstwem, jakie można pomyśleć przeciwko byciu"4 - wykorzystuje tę Heideggerowską deklarację, czyniąc $\mathrm{z}$ niej trampolinę dla własnej. Powyższe stwierdzenie nie zraża Tischnera, przeciwnie, dostrzega w nim zachętę, impuls skłaniający do podjęcia polemiki z Heideggerem ${ }^{5}$. Nie podąży on tropem Fryburczyka, który zaleca, by „prześwit prawdy bycia” stawiać nawet ponad myślenie, co byłoby postulatem myślenia „przeciw wartościom”, czyli „wbrew subiektywizacji bytu, która czyni z niego jedynie przedmiot"6.

Tischner podziela krytyczną diagnozą Heideggera dotyczącą kondycji filozofii i filozofującego człowieka:

Człowiek zajął się „bytem”, nastawił się na to, by odróżnić przedmiot od przedmiotu, rzecz od rzeczy, by wykorzystywać jedną rzecz do panowania nad drugą, aż wreszcie sam siebie uznał za „przedmiot” „rzecz”, jedną $\mathrm{z}$ „substancji”. Zamiast poddać się prawdzie, począł poddawać prawdę

3 Tenże, Dzieła zebrane. Etyka a historia. Wykłady, oprac. D. Kot, Kraków 2008, s. 214.

${ }^{4}$ M. Heidegger, List o humanizmie, tłum. J. Tischner, w: tenże, Znaki drogi, Warszawa 1995, s. 157.

5 „Będziemy zatem z punktu widzenia Heideggera popełniać niezwykłe bluźnierstwo". Tamże, s. 213.

${ }^{6}$ M. Heidegger, List o humanizmie, s. 157. 
sobie, począł czynić z niej środek do rozszerzenia swej władzy nad byciem. W ten sposób wymknęła mu się „prawda bycia”’

Jednak w ocenie Tischnera droga proponowana przez Fryburczyka, obiecując wyjście z filozoficznego impasu, prowadzi zarazem do impasu antropologicznego, bowiem człowiek: „Spotykając się z samym sobą, natrafił na rozpacz, na nicość, na «bycie w stronę śmierci»"8.

Dla Heideggera wartości są przede wszystkim takimi pojęciami, których rodowód odsyła do tradycji nowożytnej metafizyki, a konkretnie do mistyfikującej tendencji, która dziejące się bycie sprowadzała do bytu - spetryfikowanego i zamkniętego w nieruchomej strukturze pojęć. „Myślenie według wartości" bywa podatne na deformacje i niejednokrotnie, zamiast odsłaniać, zasłania prawdę. Jednak głoszony przez Heideggera postulat porzucenia go, jest dla Tischnera utopijny i niebezpieczny. Tym bardziej, że „myślenie” jest przez Tischnera rozumiane w duchu Kartezjańskim - nie sprowadza się do teorii i aktywności intelektualnej, gdyż obejmuje całe spektrum ludzkiej egzystencji i jest raczej „byciem według wartości”.

Oś sporu budowana jest tu stosownie do dwóch założeń - w pewnym stopniu przyjmowanych arbitralnie, gdyż stanowiących punkt wyjścia całego filozoficznego projektu obu autorów. Po pierwsze, dla Tischnera byt alias bycie nie jest najważniejszym tematem i zadaniem badawczym filozofii. Czytamy: „Patrząc na osiągnięcia filozofii Heideggera poprzez pryzmat filozofii dramatu, można stwierdzić, że jest ona wynikiem redukcji dramatu ludzkiego do dramatu stworzenia. Dasein szuka ocalenia przed własną nicością w ontologii, którą czyni następnie częścią swego bytu" . Po drugie, Tischner, w przeciwieństwie do Heideggera, nie obawia się kontaminacji, która deformowałaby filozoficzny dyskurs i pozbawiała go ontologicznej wiarygodności. Można jednak przypuszczać, że o ile podziela on opinię Heideggera w kwestii zarysowanego w obrębie ontologii fundamentalnej niebezpieczeństwa reifikacji bytu - względem którego, ich zdaniem, bezbronna i bezkrytyczna okazała się filozoficzna

\footnotetext{
7 J. Tischner, Myślenie według wartości, Kraków 1993, s. 127.

8 Tamże, s. 127-128..

9 J. Tischner, Filozofia człowieka dla duszpasterzy i artystów, Kraków 1991, s. 96.
} 
tradycja - o tyle daleki jest od wymierzonych w neokantyzm obaw przed zaksjologizowaniem filozofii, która przecież nigdy nie może, a także nie powinna być zdystansowana od swego podmiotowego i osobowego źródła. Filozofia bowiem nigdy nie stanie się epifanią oderwanej od człowieka „ontologicznej prawdy”. Tischner dostrzega raczej inne niebezpieczeństwo - reifikację prawdy o człowieku. Ponadto, co widać wyraźnie, bardzo różne są wyobrażenia obu autorów na temat „źródłowości”. Wedle pierwszego szukać jej należy w „prześwicie prawdy bycia”, z pominięciem myślenia zwłaszcza aksjologicznego - jako stanowiącego relikt zsubiektywizowanej metafizyki. Wedle drugiego, właśnie wartości - poprzez które dokonuje się myślenie, przeżywanie, doświadczanie świata - stanowią osnowę „prawdziwej” egzystencji człowieka.

\section{INTERPRETACJA CZY NADINTERPRETACJA?}

A jednak, mimo dostrzegania różnic $\mathrm{w}$ zakresie filozoficznych priorytetów, w projekcie Heideggera Tischner upatruje ważny dla refleksji antropologicznofilozoficznej raport, i to zawarty w nim nie tyko implicite. Świadczą o tym powtarzające się opinie w rodzaju: „Podstawowe pytanie filozofii Heideggera dotyczy człowieka" ${ }^{10}$. Tischner wpisuje analizy Heideggera w kontekst „fenomenologii cielesności” i jako takie zestawia je z fenomenologicznymi analizami Jean-Paula Sartre’a czy Maurice'a Merleau-Ponty'ego ${ }^{11}$. A przecież ex contrario można bronić tezy - tym bardziej, że ma ona uzasadnienie w tekstach Heideggera - wedle której podstawowym pytaniem Fryburczyka nie jest, by powiedzieć za Buberem „problem człowieka” 12 , lecz „problem bytu”. Gwoli usprawiedliwienia Tischnera przyznajmy jednak, że jego diagnoza, polegająca na wykraczaniu poza fundamentalne dla Heideggera autoidentyfikacje i filozoficzne

10 Tenże, Myślenie według wartości, s. 133.

11 Tenże, Dzieła zebrane. Studia z filozofii świadomości, oprac. A. Węgrzecki, Kraków 2006, s. 200-201.

12 Por. M. Buber, Das Problem des Menschen, Werke, Bd. I: Schriften zur Philosophie, München-Heidelberg 1962, s. 307-408 (wydanie hebrajskie 1943 r.; angielskie 1947 r.; niemieckie 1947 r.; polskie przekłady: M. Buber, Problem człowieka, tłum. J. Doktór, Warszawa 1993; tenże, Problem człowieka, tłum. R. Reszke, Warszawa 1993. 
deklaracje, nie jest w myśli współczesnej odosobniona, czego dowodzi przywołanie takich autorów, jak choćby Helmuth Plessner, Helmut Fahrenbach czy Otto Pöggeler ${ }^{13}$.

Próbką odniesienia do projektu Fryburczyka będą słowa:

Dom, z którego spoglądam na filozofię Heideggera znajduje się w Polsce. Przyznaję to otwarcie, bowiem widzę w tym jakąś szansę. [...] Widzę Heideggera jako ciąg dalszy wywodzącego się od Kanta niemieckiego formalizmu. [...] Sens bycia stał się dla niego formą sensu bycia. Prawda bycia jest formą prawdy bycia. Zdecydowanie człowieka wobec śmierci jest również formą. Nawet głos sumienia, które mówi „chciej mieć sumienie", ma charakter formalny. Heidegger zdaje się wiedzieć, $j a k$ wygląda człowiek, ale nie wie, $c o$ to jest człowiek [...] Ale do tego, by człowiek odkrył prawdę bycia, formalizm nie wystarcza. Trzeba sięgnąć do tego, co jest poza formą, co wypełnia formę, do tego co jest przez formę formowane. Moim zdaniem czymś takim jest wartość. Wartość to jest elementarne $C o$ bycia. Bez takiego $C o$ bycie staje się puste, pusta staje się prawda, puste jest zdecydowanie i pusty jest głos sumienia”. [...] Niemieckiej wrażliwości na formę radbym przeciwstawić polską wrażliwość na treść, czyli wartość. Stąd moje spory z Heideggerem ${ }^{14}$.

Tischner solidaryzuje się z Heideggerem, gdy ten pozbawia substancję jej dotąd wyróżnionej pozycji, organizującej dyskurs ontologiczny, przy czym dla Tischnera głównym sprzeciwu są znane z europejskich dziejów filozofii próby substancjalistycznego ujmowania człowieka, tym bardziej, że również w ten sposób bywał rozpoznawany osobowy aspekt człowieka ${ }^{15}$. Jakkolwiek więc Heidegger zajmuje się według Tischnera człowiekiem, to jednak instrumentarium proponowane w ramach ontologii fundamentalnej nie zdoła uchwycić tego, co dla człowieku relewantne z uwagi na jego osobowy status. Autor konkluduje: „horyzont świata osoby ma charakter aksjologiczny. To dzięki i w ramach aksjologicznego horyzontu świat otaczający staje się światem otaczającym osoby, czyli środowiskiem osoby. Tego aspektu świata Husserl ani Heidegger,

${ }^{13}$ Por. J. Jagiełło, Niedokończony spór o antropologie filozoficzną (Plessner-Heidegger). Studium historyczno-analityczne, Warszawa 2011, s. 134.

14 J. Tischner, Myślenie według wartości, s. 131-132.

15 Tenże, Filozofia człowieka, s. 27. 
ani Merleau-Ponty w swych opisach nie uchwycili”'16. O człowieku nie powinno się też - co oczywiste - myśleć w kategoriach Kartezjańskiej res cogitans, bowiem „Substancja jest czymś radykalnie różnym od bytu ludzkiego” - i odpowiednio - „Rozumienie bycia nie jest sposobem bycia substancji” ${ }^{17}$. O ile jednak motywacja Heideggera wynika z zamiaru zdemaskowania błędów dotychczasowej metafizyki, o tyle dla Tischnera jest to ważne w perspektywie myślenia o człowieku jako o osobie uczestniczącej w dramacie istnienia ${ }^{18}$.

\section{3. „PROBLEM CZŁOWIEKA"}

Człowiek jest niewątpliwie jednym z bytów - wiedziano o tym od początku dziejów filozofii. Jednak człowiek jest zarazem problematyczny - jest problemem sam dla siebie, a przynajmniej tak powinien przeżywać swoje istnienie, by nie popadać w degradujący je redukcjonizm - w tym ujawnia się wyjątkowa jakość ludzkiego istnienia ${ }^{19}$. Owo istnienie wyraża się także specyficznym dla człowieka byciem - zanurzonym w dziejowość oraz nieustannie - w sposób właściwy i niewłaściwy, wprost i nie wprost, pozytywnie i negatywnie - optującym na rzecz ujawniania się sensu. Ten ostatni aspekt szczególnie interesuje Heideggera. Ale - jak twierdzi Tischner - człowiek jest czymś więcej, albo raczej - by użyć dystynkcji Karola Wojtyły i Roberta Spaemanna - jest k i m ś więcej, aniżeli Dasein, które jako „bycie przytomne” ${ }^{20}$ odnosi się do rozmaitych

16 Tenże, Dzieła zebrane. Studia z filozofii świadomości, s. 363.

17 Tenże, Filozofia człowieka, s. 69.

18 Za symptomatyczne uznamy dokonywane przez Tischnera próby konfrontowania Heideggerowskiego projektu z koncepcjami takich wyraźnie „antropologicznie” zorientowanych autorów, jak S. Kierkegaard czy F. Nietzsche. Por. J. Tischner, Spór o istnienie człowieka, Kraków 1998, s. 113-117.

19 Te wątki, pobrzmiewające w całej Tischnerowskiej filozofii człowieka, nawiązują do dwudziestowiecznej tradycji filozofii dialogu. Por. M. Buber, Problem człowieka; A.J. Heschel, Człowiek, nie jest sam, tłum. K. Wojtkowska, Kraków 2008, s. 177-184. Na nieredukowalność bytu ludzkiego zwraca też uwagę Gabriel Marcel, choć odwołuje się do pojęcia „tajemnicy”, przeciwstawiając je pojęciu „problemu”. G. Marcel, Być i mieć, tłum. P. Lubicz, Warszawa 1986, s. 87.

${ }^{20}$ Najbardziej zasłużeni polscy translatorzy Heideggera Dasein funkcjonujące 
modi swego istnienia. Człowiek nie tylko „jest”, ale także odnosi się do swojego istnienia - kształtuje je, zajmuje określone stanowisko w obliczu różnych życiowych sytuacji, podejmuje świadome decyzje. Ludzkie „rozumienie się" nie dotyczy wyłącznie bytu, lecz wyraża się egzystencjalnie - jest sposobem „bycia w świecie”, jednak niesprowadzalnym do Heideggerowskiego Dasein, gdyż nie dającym się wyczerpać w instrumentalno-użytkowej aktywności, bowiem najpełniej wyrażanym w sferze etycznych interpersonalnych odniesień. Człowiek, by odwołać się do znanej dystynkcji Abrahama J. Heschela, uosabia nie tylko „byt ludzki” (human being), lecz także - ponieważ ma on przywilej oraz obowiązek odnoszenia się do swojej egzystencji - powinna ona przybierać postać „bycia ludzkim” (being human) ${ }^{21}$, czyli bycia „na sposób ludzki”, modo humano. Wprawdzie byt ludzki „domaga się bycia ludzkim”22, ale zarazem i tym samym nie wymusza go, raczej stanowi podstawę i przesłankę jego realizacji. Wybieranie tego ostatniego - rozumianego jako realizowanie w sposób właściwy moralnie „bycia ludzkim” - nie wynika z samego faktu ludzkiego istnienia, lecz jest funkcją intencjonalnie podejmowanych przez człowieka wyborów i decyzji. Człowiek, będąc bytem i rozumiejąc się na byciu, transcenduje zarówno sferę ontyki, jak i sferę ontologii. Zarówno bowiem w świecie bytu, jak i w świecie bycia, centralne miejsce przysługuje człowiekowi, jako będącemu czy dziejącemu się. Jednak nie to, jak uważa Tischner, stanowi o swoistości ludzkiego istnienia - nie byt, ani „bycie w świecie”, lecz zdolność do rozumienia się na dobru i złu, zdolność wybierania między wartościami, często pozostającymi we wzajemnym konflikcie, nawet nierozstrzygalnym. Czytamy: „Bez uwzględnienia aksjo-

w jego ontologii fundamentalnej oddają w nieco odmienny sposób. Najbardziej znane są propozycje Bogdana Barana: „jestestwo”, „bytowanie”, „istnienie” (por. M. Heidegger, Bycie i czas, s. 611, passim), Krzysztofa Michalskiego: „bycie rozumiejące” (por. K. Michalski, Heidegger i filozofia wspótczesna, Warszawa 1978, s. 28-30) lub Józefa Tischnera: „bycie przytomne" (por. J. Tischner, Dzieła zebrane. Współczesna filozofia ludzkiego dramatu. Wykłady, s. 55, 167 lub „przytomność”, tamże, s. 203). Interesujące propozycje translatorskie zgłaszała też Barbara Skarga, jednak ta autorka posiłkowała się głównie francuskimi, a zatem już tłumaczonymi tekstami.

${ }^{21}$ A.J. Heschel, Kim jest człowiek?, tłum. K. Wojtkowska, Łódź-Warszawa 2014, s. 63-69.

${ }^{22}$ Tamże, s. 65. 
logicznego wymiaru bytu ludzkiego, rozumienie tego bytu nie jest, jak się zdaje, możliwe. Wartości, rzeźbiąc ludzką przestrzeń, zarazem otwierają i zamykają człowieka przed drugim człowiekiem"23. Istotna jest wreszcie gotowość do solidaryzowania się z tymi wartościami, w których człowiek upatruje ocalenia ${ }^{24}$. To ocalenie nie może być osiągnięte na trwałe, lecz jest horyzontem, ku któremu człowiek nieustannie podąża. Ta jego peregrynacja ma charakter dramatyczny, bo przebiega w czasie, w którym padają pytania i odpowiedzi, w czasie, w którym dochodzi do spotkania z osobą - jakże różnego od napotykania bytu. Odbywa się ona w obliczu zagrożenia złem, a zatem na scenie, która również w żadnej mierze nie pokrywa się z uniwersum bytów, a także nie jest wyrażalna w kategorii „bycia w świecie". Ta egzystencjalna wędrówka wymaga porzucania jednych osi aksjologicznych na rzecz innych, przy czym samo „bycie autentyczne” nie stanowi gwarancji sukcesu, gdyż przebiega w spektrum skomplikowanej struktury aksjologicznej, a porzucanie i wybieranie wartości nie odbywa się w autonomicznym świecie Dasein, lecz podejmowane jest wobec Innego. Dlatego dla Tischnera ocalenie polega nie tyle na utrzymywaniu się w swoim byciu, ile jest ono byciem przebiegającym w sposób usprawiedliwiony. To usprawiedliwienie nie przychodzi od strony bytu, lecz od strony Dobra - nie jest ontyczne ani ontologiczne, lecz agatologiczne. Rękojmię ocalenia daje człowiekowi możliwość ukierunkowania się na Dobro, które jest rozumiane, przeżywane i doświadczane nie tylko kulturowo, lecz etycznie. Tylko takie Dobro „prowadzi do związania świadomości Ja z wartościami, które mogą wyjść obronną ręką w sporze ze złem”25. Dzięki takiemu Dobru ludzkie Ja „nigdy nie będzie przekonane, że jest złe. Zawsze bowiem znajdzie się jakiś dobro, jakaś wartość, pod dachem której poszuka sobie schronienia"26.

${ }^{23}$ J. Tischner, Filozofia dramatu, s. 226.

${ }^{24}$ Tenże, Solidaryzacja i problem ewolucji świadomości, w: Studia z teorii poznania i filozofii wartości, red. W. Stróżewski, Wrocław, s. 91-102.

${ }_{25}$ Tenże, Filozofia dramatu, s. 252.

26 Tamże. 


\section{DOBRO I AUTENTYCZNOŚĆ - DWA HORYZONTY MYŚLENIA O CZŁOWIEKU}

Heideggerowskie odczarowanie bytu byłoby wedle Tischnera krokiem we właściwą stronę, ale zaledwie pierwszym. Porzucenie myślenia o człowieku w kategoriach substancji - do czego implicite zachęca Heidegger - nie odsłania jeszcze prawdy o człowieku jako podmiocie dramatycznym, dla którego kluczem do sensu jest nie tyle poręczność, ile Dobro. To ostatnie jest dla Tischnera transcendentalnym warunkiem ludzkiego „bycia w świecie”27. Tischner, niejako w opozycji do Heideggera deklaruje: „Myślenie według wartości stara się wykraczać poza horyzont bycia, pokazuje, że refleksja nad subiektywnością nie musi być subiektywizmem, a słynna »rzecz«, do której wciąż trzeba wracać, to po prostu inny człowiek"28. A zatem uwaga Heideggera dotycząca jego projektu, że „właściwą substancją Dasein jest egzystencja” - Tischnerowi nie wystarcza. Nie poszukuje on prawdy o człowieku w przestrzeni bycia, gdyż dotarcie do niej - jak zakłada - wymaga odwołania się „do transcendentaliów, które są "poza bytem i niebytem»" ${ }^{2}$. Aluzja do „inaczej niż być” Emmanuela Lévinasa jest tu aż nadto wyraźna ${ }^{30}$.

Czym jednak jest Dobro, jeśli nie bytem? Czy zawieszenie sądu dekretującego jego istnienie nie zawiesza jego ważności? - z takimi zarzutami Tischner spotykał się niejednokrotnie. I odpowiadał: „Dobro nie wymaga ode mnie, abym akceptował jego istnienie. Dobro wymaga ode mnie, abym dał chleb głodnemu [...] a zatem istnienie czy nieistnienie takiego bytu jak Dobro nie wpływa w żaden sposób na moje zachowanie wobec drugiego człowieka”31. Czy jednak taka enuncjacja, niewątpliwie prowokacyjna, nie jest kardynalnym grzechem przeciw ontologii? Tischner

${ }^{27}$ Por. K. Tarnowski, Usłyszeć niewidzialne. Zarys filozofii wiary, Kraków 2005, s. 193-194, przypis 16.

28 J. Tischner, Myślenie według wartości, s. 14. Por. Przestrzeń obcowania z drugim, Przestrzeń obcowania $z$ drugim, „Analecta Cracoviensia” (1977), t. IX, s. 67-86.

29 Tenże, Filozofia człowieka, s. 29.

${ }^{30}$ E. Lévinas, Inaczej niz być lub ponad istotą, tłum. P. Mrówczyński, Warszawa 2000.

${ }^{31}$ J. Tischner, Uprawiam filozofię dobra, w: Rozmowy o filozofii, red. A. Zieliński, M. Bagiński, J. Wojtysiak, Lublin 1996, s. 261. 
pośrednio oddala ten zarzut: „Ontolog [...] nie ma nic do powiedzenia w zakresie tego, co dzieje się między mną a drugim człowiekiem”32.

W perspektywie Dasein bycie autentyczne, to bycie sobą i dlatego podstawową troską Dasein jest troska o własne bycie. Tischner zastanawia się:

Wyobraźmy sobie jednak, że Dasein jest „autentycznie złe”. Czy będzie wtedy sobą? Czy do Sobości nie jest potrzebne dobro? Jeśli tak, to trzeba powiedzieć, że ontologiczny dramat człowieka nie jest jego dramatem najważniejszym. Człowiek może umrzeć za to, co niewidzialne. Może poświęcić swój „autentyczny byt” w imię tego, co jest „ponad bytem". Dramat ontologiczny jest tylko wstępem do dramatu agatologicznego ${ }^{33}$.

W cytowanym fragmencie Tischner nie najszczęśliwiej użył słowa "potrzeba”, bowiem z kontekstu wynika, że idzie mu „pragnienie”. Człowiek nie tyle potrzebuje Dobra, ile go pragnie. I również dziedzina moralności - nie jest wyznaczana sferą potrzeb, lecz sferą pragnień. Czynów etycznych nie podejmuje się w imię odkrywanej przez Dasein prawdy bycia, lecz w imię stawienia czoła wezwaniu skierowanemu przez Drugiego. Apel Drugiego nie mieści się w realiach „bycia w świecie”, lecz je przekracza oraz je poprzedza.

Heidegger wyklucza możliwość istnienia rozziewu między prawdą bycia, ujawniającą się w „byciu sobą”, a powinnością moralną. Będąc sobą, Dasein realizuje zarazem powinności moralne. W późniejszym okresie Heidegger przesuwa akcent na „otwartość”, rozumianą zwłaszcza jako wsłuchiwanie się w głos bycia, które przemawia - co miałaby sygnalizować filiacja słów sein i sagen. W ten sposób formalny wymiar etyki Heideggera zostaje dopełniony wymiarem materialnym: odpowiedź na pytanie „Jak mam żyć?” brzmi: „Mam wsłuchiwać się w głos bycia i pozostawać mu wiernym”. Przywołajmy cenną uwagę: „Wczesny Heidegger akcentował bardziej odpowiedzialność wobec siebie, sensu własnego bycia, własnej egzystencji (stan Insichstehen), późny Heidegger kładł nacisk na

32 Tamże, s. 262.

${ }^{33}$ J. Tischner, Filozofia człowieka, s. 96-97. 
odpowiedzialność wobec wy-darzającej się prawdy bycia"34. Jednak dar czego Heidegger nie uwzględnia - wskazuje na uprzedniość darczyńcy względem obdarowanego. A zatem realność daru nie sprowadza się do rozumienia, podejmowanego w sposób monologiczny, lecz je poprzedza - jest funkcją wolnej decyzji Drugiego. Niezależnie od rozróżniania między „wczesnym” a „późnym” Heideggerem, Tischner skłonny jest oba te projekty rozpatrywać raczej wedle klucza antropologicznego, niż ontologicznego, którego zastosowanie rekomenduje sam Heidegger. Według Tischnera „pierwszy Heidegger polegał właśnie na tym prometejskim: wyzwól się, a poznasz prawdę”, z kolei „drugi Heidegger jest charakterystyczny przez to, że »prawda cię wyzwoli «"35. Głównie w tym, jak sugeruje Tischner, wyrażać by się miała różnica.

\section{KONKLUZJA - PROTOKÓŁ FILOZOFICZNYCH ROZBIEŻNOŚCl}

Różnica między Tischnerem i Heideggerem jest zasadnicza. Heidegger dowodzi, że wartości są indyferentne i nie rodzą w człowieku powinności moralnych. Tischner postrzega wartości jako żywe drogowskazy, będące czymś niesprowadzalnym do pojęć, gdyż są one pewnymi „prze(d) sądami”, stanowiącymi nie tylko warunki ludzkiego interpretowania rzeczywistości moralnej, ale także ludzkiego odnajdywania się w niej. Dobro i zło nie są przesądem Boga - jak twierdził Nietzsche - są one przesądem człowieka, przesądem, na którym ufundowane jest jego człowieczeństwo. Jeśli dla Heideggera ludzki dostęp do wartości jest zawsze dziejowy i tym samym zapośredniczony pewnymi przedrozumieniami - to dla Tischnera owe przedrozumienia zawierają już w sobie komponent aksjologiczny, funkcjonują jako mające wartość. I jako takie są od początku rozpoznawane i rozumiane. Heidegger ufa byciu i w prawdzie bycia odnajduje prawdy życia moralnego. Tischner przeciwnie, odróżnia bycie od moralności, zgodnie ze znaną dystynkcją Sein vs. sollen. Wedle Tischnera, który podąża tropem Lévinasa, podstawowym orzeczeniem na temat bycia jest

${ }^{34}$ K. Stachewicz, Etyka a myślenie Heideggera - uwagi wstępne, w: tenże, Człowiek $i$ jego ethos. Studia - szkice - polemiki z antropologii filozoficznej i etyki, Poznań 2011, s. 323.

35 J. Tischner, Dzieła zebrane. Etyka a historia. Wykłady, s. 170-171. 
to, że chce ono przetrwać za wszelką cenę - również za cenę moralności, która w perspektywie tego dążenia bywa instrumentalizowana. I tak, jak Lévinas pouczał, że pierwsze i najważniejsze pytanie filozofii dotyczy nie tyle ontologii, ile etyki, a zatem nie jest ono Leibnizjańskim: „dlaczego istnieje raczej coś niż nic?”, lecz etycznym: „czy mam prawo być?” ${ }^{36}$. Nie ontologia, lecz etyka będzie tu najważniejszym filozoficznym oknem, z którego powinno się patrzeć na człowieka. dlatego też również Tischner, w opozycji do Heideggera, będzie upatrywał zasadniczej różnicy między człowiekiem a byciem rozpoznawanym przez Dasein. Człowiek jest zawsze bytem jednostkowym, zindywidualizowanym, mającym przywilej bycia osobą i „skazanym na subiektywność". Heidegger postuluje, by człowiek wyzwolił się z pęt subiektywności. Czy jest to jednak możliwe? - to pytanie pozostawmy bez odpowiedzi.

Tischner zgadza się z Heideggerem w kwestii rangi „troski”, jako egzystencjału nie tylko kluczowego w ramach ontologii fundamentalnej, ale też ważnego antropologicznie, jednak różni się w swej diagnozie. Na pytania: Dlaczego Dasein (człowiek) się troszczy oraz o co się troszczy? - odpowie inaczej niż Heidegger. O ile bowiem ten ostatni poprzestaje na wskazaniu na trwogę, rodzącą troskę, a zakorzenioną w „byciu ku śmierci” - będącym fundamentalnym "nastrojeniem” Dasein - o tyle Tischner odwołuje się do Transcendencji oraz relacji międzyosobowej, która niesie z sobą komponent etyczny. U Heideggera, zwłaszcza wczesnego, „transcendencja” wskazuje na różnicę ontologiczną, a także na okoliczność, że Dasein jest zawsze „poza sobą”, ponieważ jest ono otwarte na świat. Natomiast u Tischnera, podobnie jak u dialogików, Transcendencja, rozumiana osobowo, poprzedza wszelkie ludzkie bycie w świecie i wszelkie otwieranie się na świat.

Według Heideggera sens bycia, którego jedynym świadkiem i beneficjentem jest Dasein, wychodzi na jaw za sprawą skończoności, która z kolei jest funkcją czasowości Dasein. Skończoność jest zatem okolicznością produktywną, gdyż dopiero w jej świetle może się ujawnić prawda bycia. Niezależnie od docenienia tej perspektywy - skądinąd doniosłej również antropologicznie, gdyż znaczącej drogę tych nurtów antropologii, które

${ }^{36}$ E. Lévinas, O Bogu, który nawiedza myśl, tłum. M. Kowalska, Warszawa 1994, s. 258 . 
eksponowały historyczność człowieka (Dilthey, Ortega) oraz jego nieprzystosowanie (od Protagorasa po Gehlena) - Tischner w kwestii skończoności wydaje się podążać raczej za Lévinasem, niż za Heideggerem. Dla Tischnera ludzkie „rozumienie się” na skończoności musi być zapośredniczone i poprzedzone (zarówno logicznie jak temporalnie) przez „rozumienie się” na nieskończoności - a nie odwrotnie. Nieskończoność nie jest ani multiplikacją skończoności, ani budzącą trwogę trampoliną, ani prywacją bytu. Nieskończoność jest niepoznawalna, nie pozwala się problematyzować. A jednak, jako żywa epifania, jest obecna w twarzy Drugiego. Metafora twarzy - przypomnijmy - funkcjonuje $\mathrm{u}$ Tischnera w sposób zbliżony do sensu nadanego jej przez Lévinasa ${ }^{37}$. Również głos sumienia jest słyszalny nie jako dobiegający z ontologicznej głębi, lecz jako dostępny i słyszalny dopiero w wydarzeniu spotkania. Dopiero spotkanie „otwiera agatologiczny i aksjologiczny horyzont istnienia”38. spotkanie jest tu traktowane jako wydarzenie, a zatem jest darem, którego udzielają sobie wzajemnie jego uczestnicy - ci, którzy jako spotykający się są obecni przed sobą, dla siebie, „wobec siebie”.

O ile u Heideggera zarówno „bycie właściwe”, jak i „upadanie” należą do rzeczywistości ontologicznej, gdyż współtworzą ją jako niepomijalne i komplementarne jej elementy, o tyle Tischner, niejako w duchu Karla Jaspersa, dokonuje ich waloryzacji. Człowiek bytujący w sposób autentyczny wybiera siebie, a podejmowane przezeń akty solidaryzacji egotycznej - rozumiane jako akty wolnego, dojrzałego i odpowiedzialnego wybierania własnej egzystencji - są przeciwstawiane „wybieraniu” pozornemu, anonimowemu, nieautentycznemu, eo ipso będącemu funkcją świadomości fałszywej, „wewnętrznie zakłamanej”39. Jeśli u Heideggera

37 „Twarz jest tekstem bez kontekstu. [...] Na świecie bez wartości ona jedna chce być wartością [...] dlatego, że chce mieć wartość, że chce być pełna sensu”. J. Tischner, Filozofia dramatu, s. 34.

38 Tenże, Myślenie według wartości, s. 521. Doświadczenie agatologiczne jest wcześniejsze i stanowi absolutny horyzont aksjologicznej orientacji w świecie; doświadczenie aksjologiczne pojawia się jako jego praktyczna konsekwencja. Pierwsze odsłania strukturę wartości - niesprowadzalnych do dobra, choć mających w nim swój początek i czerpiących z niego swój sens - jako zagrożoną. W obrębie drugiego człowiek podejmuje praktyczne działania na rzecz afirmacji ładu aksjologicznego oraz własnego w nim uczestnictwa, będącego warunkiem ocalenia. Por. tamże, s. 516, passim.

39 J. Tischner, Spór o istnienie człowieka, s. 117. 
kategoria „Się" [das Man] funkcjonuje w obrębie analityki Dasein prowadzonej w planie ontologii fundamentalnej, to u Tischnera, przyjmując sens antropologiczny, ulega wyraźnemu zwaloryzowaniu. Toteż autor Sporu o istnienie człowieka pyta retorycznie: „Czym jest słynne «Się», jeśli nie młodzieńczą próbą naśladowania otoczenia i jego pozornych bohaterów? Czym jest «gadanina», jeśli nie młodzieńczym pozorem oryginalności, która «mówi» to, co «się mówi», sądzi to, co «się sądzi», która postępuje tak, jak »się postępuje«?”40. Kolejny cytat nie pozostawia wątpliwości, że Heideggerowskie "Się” jest przez Tischnera odczytywane w zaksjologizowanym kontekście antropologicznym, a nawet więcej - ma ono wymowę jawnie normatywną, stanowi negatywną ocenę ludzkiego postępowania: „Utrata wolności oznacza upadek w to, co Heidegger nazwie «Się»: «się» mówi, «się» robi, ma «się» określone poglądy itp. Postawę «Się» nazywamy zazwyczaj «nieautentycznym sposobem bycia»"41. To, co u Heideggera jest ontologiczną deskrypcją, u interpretującego go Tischnera przeobraża się w antropologiczno-etyczną preskrypcję - opis „bycia w świecie” uzyskuje nową, tym razem normatywną wykładnię. Co więcej, w kategorii upadania - teraz interpretowanej na sposób antropologiczny i mającej wymowę etyczną - Tischner dostrzeże klucz do Heideggerowskiej ontologii: „Upadanie i nieustanne próby podźwignięcia się z upadku - oto cały Heidegger" 42 .

Pamiętamy, że zagadnięty przez młodego czytelnika - „Kiedy napisze Pan etykę?" ${ }^{33}$ - Heidegger oświadczył, że już to uczynił, odsyłając go do opracowanego przez siebie projektu ontologii fundamentalnej, zorganizowanej wokół pytania o prawdę bycia. Jednak Tischnera nie zadowoliła taka odpowiedź. Człowiek sprowadzony do kategorii Dasein i przez nią problematyzowany, nie jest bowiem tym, w kim mogłoby się ujawnić

40 Tamże.

${ }^{41}$ Tamże, s. 134. Dla uzupełnienia dodajmy, że Tischner w tym zakresie i o tyle dostrzega niedostatek Heideggerowskiej analizy Dasein, o ile uznaje, że nie jest ona adekwatną reprezentacją człowieka traktowanego jako osoba ludzka. I tu pojawiają się wyraźne aluzje do Lévinasa, jako kontestatora Heideggerowskiego „redukcjonizmu antropologicznego”: „Osobie nie chodzi już o «byt» czy o «bycie», lecz o jakość bycia, która transcenduje «bycie»". Tamże, s. 168.

${ }^{42}$ J. Tischner, Uprawiam filozofie dobra, s. 263.

${ }^{43}$ M. Heidegger, List o humanizmie, s. 160. 
to, co w najgłębszy sposób określa ludzką wyjątkowość. Ta wyjątkowość i bezprecedensowość wyraża się dopiero w byciu osobą, podmiotem dramatu, uczestnikiem interpersonalnych dialogicznych relacji. Właśnie takiej perspektywy, nie bez racji, bronił autor Filozofii dramatu.

\section{BIBLIOGRAFIA}

Buber M., Das Problem des Menschen, Werke, Bd. I: Schriften zur Philosophie, München-Heidelberg 1962, s. 307-408 (wydanie hebrajskie 1943 r.; angielskie 1947 r.; niemieckie 1947 r.; polskie przekłady: M. Buber, Problem człowieka, tłum. J. Doktór, PWN, Warszawa 1993; M. Buber, Problem człowieka, tłum. R. Reszke, Warszawa 1993.

Heidegger M., Bycie i czas, tłum. B. Baran, Warszawa 1994.

Heidegger M., List o humanizmie, tłum. J. Tischner, w: tenże, Znaki drogi, Warszawa 1995. Heschel A.J., Człowiek, nie jest sam, tłum. K. Wojtkowska, Kraków 2008.

Heschel A.J., Kim jest człowiek?, tłum. K. Wojtkowska, Łódź-Warszawa 2014.

Jagiełło J., Niedokończony spór o antropologię filozoficzną (Plessner-Heidegger). Studium historyczno-analityczne, Warszawa 2011.

Lévinas E., Inaczej niż być lub ponad istotą, tłum. P. Mrówczyński, Warszawa 2000.

Lévinas E., O Bogu, który nawiedza myśl, tłum. M. Kowalska, Warszawa 1994.

Marcel G., Być i mieć, tłum. P. Lubicz, Warszawa 1986.

Michalski K., Heidegger i filozofia wspótczesna, Warszawa 1978.

Stachewicz K., Człowiek i jego ethos. Studia - szkice - polemiki z antropologii filozoficznej i etyki, Poznań 2011.

Tarnowski K., Ustyszeć niewidzialne. Zarys filozofii wiary, Kraków 2005.

Tischner J., Filozofia człowieka dla duszpasterzy i artystów, Kraków 1991.

Tischner J., Filozofia dramatu, Paryż 1990.

Tischner J., Dzieła zebrane. Studia z filozofii świadomości, oprac. A. Węgrzecki, Kraków 2006.

Tischner J., Dzieła zebrane. Etyka a historia. Wykłady, oprac. D. Kot, Kraków 2008.

Tischner J., Dzieła zebrane. Współczesna filozofia ludzkiego dramatu. Wykłady, oprac. D. Kot i A. Węgrzecki, Kraków 2012.

Tischner J., Myślenie wedlug wartości, Kraków 1993.

Tischner J., Przestrzeń obcowania $z$ drugim „Analecta Cracoviensia” (1977), t. IX, s. 67-86.

Tischner J., Solidaryzacja i problem ewolucji świadomości, w: Studia z teorii poznania i filozofii wartości, red. W. Stróżewski, Wrocław, s. 91-102.

Tischner J., Spór o istnienie człowieka, Kraków 1998.

Tischner J., Uprawiam filozofię dobra, w: Rozmowy o filozofii, red. A. Zieliński, M. Bagiński, J. Wojtysiak, Lublin 1996. 